DOI: https://doi.org/10.34069/AI/2021.48.12.20

How to Cite:

Hudimova, A., Zaverukha, O., Karpenko, Y., Stelmakh, O., \& Lialiuk, G. (2021). Gender study of the student youth's psychological well-being during coronavirus lockdown: a comparative analysis. Amazonia Investiga, 10(48), 189-199. https://doi.org/10.34069/AI/2021.48.12.20

\title{
Gender study of the student youth's psychological well-being during coronavirus lockdown: a comparative analysis
}

\section{Гендерне дослідження психологічного благополуччя студентської молоді впродовж локдауну через коронавірус: порівняльне аналізування}

Received: October 21, 2021

Accepted: December 15, 2021

\author{
Written by: \\ Alisar Hudimova ${ }^{79}$ \\ https://orcid.org/0000-0001-9996-0674 \\ Olha Zaverukha $^{80}$ \\ https://orcid.org/0000-0003-2701-2215 \\ Yevhen Karpenko ${ }^{81}$ \\ https://orcid.org/0000-0002-4046-0410 \\ Oksana Stelmakh ${ }^{82}$ \\ https://orcid.org/0000-0002-4097-6388 \\ Galina Lialiuk ${ }^{83}$ \\ https://orcid.org/0000-0002-4819-6247
}

\begin{abstract}
Research conduction and substantiation of gender semantic parameters of psychological well-being of students $(\mathrm{n}=101)$ during coronavirus self-isolation using empirical and theoretical methods. The findings revealed that student youth experience anxiety and depressive symptoms $(\mathrm{t}=-2.2 ; \mathrm{p}=.05)$. Boys were discovered to have cyclothymic, abrupt binary mood swings $(t=2.4 ; p=.05)$. Respondents tend to focus on the various activities available in a lockdown setting to protect their mental state. It was stated that the proclivity to displace anxious thoughts is a distinct feature of Group 1 (boys, $n$ $=49$ ). It is noted that future attempts to "escape" from the current situation may result in depression in Group 1 respondents $(\mathrm{t}=-2.2 ; \mathrm{p}$ $=.05)$. Group 2 (girls, $\mathrm{n}=52$ ) has been shown to be psychologically more vulnerable to the effects of forced lockdown and the increase in morbidity due to social distance and isolation, uncertainty about the future, and hypochondriac tendencies. It is argued that Group 1 respondents are
\end{abstract}

\begin{abstract}
Анотація
Проведено дослідження та обгрунтування за допомогою емпірико-теоретичних методів гендерних змістових параметрів психологічного благополуччя студентської молоді впродовж коронавірусної самоізоляції (n = 101). Встановлено, що студентська молодь потерпає від тривожності та депресивних симптомів $(\mathrm{t}=-2.2 ; \mathrm{p}=.05)$. 3'ясовано, що для хлопців характерна циклотимність, різка бінарна зміні настрою $(\mathrm{t}=2.4 ; \mathrm{p}=.05)$. Задля захисту психічного стану респонденти прагнуть сконцентруватися на різних видах діяльності, що доступні в умовах локдауну. Констатовано, що тенденція до витіснення тривожних думок яскраво виражена в Групі 1 (хлопці, $\mathrm{n}=49$ ). Зазначено, що спроби “втекти" від наявної ситуації у перспективі можуть призвести до розвитку депресії у респондентів Група $1(\mathrm{t}=-$ $2.2 ; \mathrm{p}=.05$ ). Доведено, що в Групі 2 (дівчата, $\mathrm{n}=52$ ) психологічно більш вразливі до впливу вимушеного локдауну та росту
\end{abstract}

\footnotetext{
${ }^{79} \mathrm{PhD}$ in Psychology of Department Practical and Clinical Psychology, Odesa I. I. Mechnikov National University, Odesa, Ukraine.

${ }^{80}$ Candidate of Psychological Sciences, Lecturer of the Department of Practical Psychology and Pedagogy, Lviv State University of Life Safety, Lviv, Ukraine.

${ }^{81}$ Doctor of Psychological Sciences, Associate Professor of the Department of Psychology, Lviv State University of Internal Affairs, Lviv, Ukraine.

${ }^{82}$ Candidate of Psychological Sciences, Senior lecturer at the Department of Practical Psychology and Pedagogy, Lviv State University of Life Safety, Lviv, Ukraine.

${ }^{83}$ Doctor of Pedagogical Sciences, Associate Professor of Psychology, Lviv State University of Internal Affairs, Lviv, Ukraine.
} 
psychologically vulnerable to the coronavirus situation because they have feelings about the future, but personal alienation, secrecy, and the ability to abstract mitigate the self-isolation's negative effects on their psychological wellbeing.

Key words: anxiety, depression, mental health, gender, students.

\section{Introduction}

Coronavirus is a catastrophic global epidemic that directly affects all of us. The outbreak and spread of COVID-19 have affected health in general, as well as psychological well-being (Fiorillo \& Frangou, 2020). The virus outbreak is still spreading, and infections and deaths are being recorded on a daily basis. There is a study that identified the semantic parameters of spatial self-regulation throughout the progression of the global pandemic (Khmiliar et al., 2020).

Based on a review of current data, Brooks et al. (2020) concluded that quarantine is adversely related to a variety of psychosocial factors, such as post-traumatic stress symptoms and anxiety. Numerous studies have been conducted to examine the effect of the coronavirus pandemic on the mental health of different demographics or the broader population. For example, among health professionals, women, children, and youth (Cielo, Ulberg \& Di Giacomo, 2021; Rossi et al, 2020; Kang et al, 2020; Merlo et al, 2021; Ranieri et al, 2021; Wilczyńska et al, 2021; Zhou, 2020; Fegert et al, 2020; Ravens-Sieberer et al, 2021). Most researches focus at anxiety, mental disorders, and depression to see how they affect psychological well-being. As a result, studies have found that as the coronavirus global epidemic breakthroughs, young people frequently experience anxiety (Parola et al, 2020), mental distress (Khan et al, 2020; Yunus et al, 2020), depression (Mekonen et al, 2021; Padrón et al, 2021), and declining psychological well-being (Idowu et al, 2020). Persons younger than 35 years, women, students, and anyone who is concerned about the safety of a cherished another are among those at high risk of negative consequences (Charles et al., 2021). As a result, gender is the most important factor in deciding whether or not to intervene in public health. захворюваності у зв'язку 3 соціальною дистанцією та ізоляцією, невизначеністю стосовно майбутнього та іпохондричних схильностей. Обгрунтовано, що не можна відкидати психологічну вразливість респондентів Group 1 до ситуації 3 коронавірусом, адже у них присутні переживання стосовно майбутнього, проте деяка особистісна відчуженість, закритість та вміння абстрагуватися згладжує негативний вплив самоізоляції на їх рівень психологічного благополуччя.

Ключові слова: тривожність, депресія, психічне здоров'я, гендер, студенти.

Student youth are an unique demographic with productive lifestyle behaviors centered on personal relations, physical and university activities, travel, as well as social events. Their lives have been drastically altered as a result of forced self-isolation and the suspension of educational institutions (Villani et al., 2021). Students experience more significant disruptions in their lives than other groups in society, including changes in living conditions, employment, and education. Student youth, in general and especially, have expressed concern about regarding the COVID-19 outbreak's impact on their educational success and opportunity to find work. Based on survey data, researchers Huckins and colleagues (2020) revealed that students seem to be more anxious and depressed during this pandemic than in earlier educational years. Coronavirus' social isolation and other limitations can result in undesirable psychological conditions such as anxiousness as well as fear, which can have an impact on the psychological well-being of student youth (Ozer, 2020). Mental health deterioration was linked to maladaptive behavior, such as increased telephone use and decreased physical activity. Villani et al. (2021) discovered that students are vulnerable to mental trauma following stressful experiences such as emergency situations. Young people aged 13 to 24 report significantly higher rates of apprehension regarding COVID-19 but also trauma, as well as an expansion in somatic symptoms and a reduction in general well-being (Levita et al, 2020). Prolonged school closures and spending all of one's time at home can cause anxiety and frustration in youth (Brooks, 2020; Dalton, 2020).

When synchronous virtual education is compared to traditional methods, the scientists claim that 


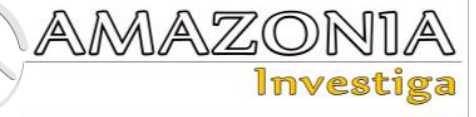

the influence on students' well-being may be strongly negative to high stress levels and isolation, as well as depressed mood (Besser et al., 2020).

Gender is a significant determinant in identifying the risks associated with COVID-19, which assisted in acknowledging psychosocial stressors (Rana et al., 2021). The psychological well-being of male and female students differs. Subjective changes are more likely to be reported by women. This is consistent with previous evidence that women rate events as more serious than men, possibly due to their ability to express a broader range of more powerful and complex emotions (Pigaiani et al., 2020). Lockdown poses a danger to student youth's health (Singh et al, 2020).

Sing and colleagues (2020) discovered gender education dissimilarity and psychological stress. With increasing levels of education and time spent on the pandemic, men's psychological stress has increased and accumulated a massive negative impact. The findings of gender differences in the needs of the psychological support service revealed that women had a greater need for psychological support than men. It has been discovered that men can cope with stress on their own, whereas women require professional assistance. Dang and Nguyen (2020) conducted research in six different countries on how pandemics affect men and women and came to the following conclusions. As a result, women are more prone than men to lose one's positions in organizations as a result of a pandemic. Furthermore, women are more concerned about other potential COVID-19 consequences, such as increased gender-based violence, maternal and child health, income loss, and other social consequences (Dang \& Nguyen, 2020). Due to mental health issues, the pandemic of coronavirus has had a considerable influence on women (Chang, 2020). In between a disease outbreak, mental health was compared in medical studies. Women were found to be more prevalent than men to report higher levels of psychological distress, anxiousness, and feelings of hopelessness (Pieh et al, 2020; Daly et al, 2020; Proto \& Quintana-Domeque, 2021). Women seem to be more frightened of coronavirus (Broche-Pérez, 2020; Giordani et al, 2021) and have a greater incidence of disease outbreak suicidal behavior. This list of studies demonstrates that women are at a higher risk of mental disorders and have lower psychological well-being as the pandemic progresses (Hossain et al, 2020; Vindegaard, Benros, 2020; Xiong et al, 2020).
Hypothesis. We believe that the change in daily routine as a result of the COVID-19 global epidemic provokes emotional and psychological disorders, as well as the development of an overvalued attitude toward the health of students, primarily women. We anticipate that an increase in time spent in social isolation will have a negative impact on respondents' psychological well-being.

The aim. The comparison of individual characteristics and changes in the psychological well-being of student youth depending on gender as a result of the forced lockdown due to coronavirus outbreak will be empirically investigated and theoretically supported.

\section{Materials and methods}

The substantive components of the gender research methodology of psychological wellbeing of student youth during forced selfisolation are tested, valid psychodiagnostic tools that provide a comprehensive study of the studied phenomena (Halian et al., 2020; Hudimova, 2021; Whitman et al., 2020; 1981; Zaitsev \& Khvan, 2011; Vagg, Spielberger, and O'Hearn Jr, 1980; Dellinger, 1989). Researchers tested these methodological complexes in the study of safe educational space (Blynova et al., 2020), taking into account student teaching (Ozer, 2020; Khan et al, 2020; Huckins et al, 2020; Merlo et al, 2021; Padrón et al, 2021), respondents' mental states (Popovych et al., 2020a), motivation studies and self-regulatory processes (Pigaiani et al, 2020). The study of current youth phenomena receives special attention (Cielo et al, 2021; Hawke et al, 2020; Levita et al, 2020; Parola et al, 2020; Popovych, 2021a; 2021b). The interdisciplinary dimension (Fiorillo \& Frangou, 2020; Shevchenko et al., 2020a; 2020b) is considered, as are studies of other human activities (Nosov et al., 2020a; 2020b; Pinkovetskaia et al., 2021; Zinchenko et al., 2020). The conducted study contains methodological principles that were used in the development of the current gender research of student youth.

Participants. The study included 101 people aged of 18 and 22 years. The study was conducted using survey questionnaire on the Google Form system as the global epidemic progressed. Terms of age limitations of the research group, information about the study is published on the online sites of higher education institutions in Odessa (Ukraine). The total sample was indeed defined by the amount of 
participants who accurately and totally participated in this survey.

Organization of Research. The questionnaire was filled out as part of the research procedure. Each questionnaire came with a set of instructions. The study's parameters, such as confidentiality, purpose, and timeline, are outlined in the instructions. An author's method (Hudimova, 2021) was used to collect relevant information.

The psychological and individual spheres were examined with the Warwick-Edinburgh Mental Well-being Scale (Tennant, et al., 2007) $(\alpha$-Cronbach $=.87)$; Minnesota Multidisciplinary Personality Questionnaire (MMPI-3) $(\alpha=.88)$ (Whitman et al., 2020); Leonhard-Schmischek's method for determining character accentuation (Leonhard, 1981); Spielberger-Khanin method for determining anxiety and worry ( $\alpha$-Cronbach's coefficient was $\alpha=.81$ ) (Zaitsev, Khvan, 2011; Vagg, Spielberger, and O'Hearn Jr, 1980); S. Dellinger's psychogeometric test ( $\alpha$-Crponbah coefficient was $\alpha=.82$ ) (Dellinger,
1989) and M. Luscher's Color Choice Test (Luscher \& Scott, 1971).

Procedure. The empirical methodology has been implemented in a form of a confirmative experiment. For each diagnostic method, the obtained results were interpreted separately. The subsequent stage of the study was to examine the interrelations between the disease outbreak situation and the psychological well-being of student youth.

Statistical Analysis. The data gathered was mathematically analyzed using IBM SPSS Statistics v. 23.0.0 for Windows. Correlation analysis is used in the article, which employs the Student's t-test, F-test (Fisher test), and modal distribution.

\section{Results}

The study involved representatives of the traditional gender distribution: men and women. The study found differences in psychological profiles between Group 1 (males, $\mathrm{n}=49$ ) and Group 2 (females, $\mathrm{n}=52$ ), as shown in Table 1 .

Table 1.

Contrasts in psychological profile of Group 1 and Group 2 during forced lockdown.

\begin{tabular}{|c|c|c|c|c|}
\hline Indicator & Gender & $\mathbf{M} \pm$ SD & Student's t-Test & $\Delta, \%$ \\
\hline \multicolumn{5}{|c|}{ Spielberger-Khanin method for determining anxiety and worry } \\
\hline \multirow{2}{*}{ Reactive anxiety } & Group 1 & $40.55 \pm 2.239$ & \multirow{2}{*}{$-2.1 *$} & \multirow{2}{*}{88.0} \\
\hline & Group 2 & $55.10 \pm 2.810$ & & \\
\hline \multirow{2}{*}{ Personal anxiety } & Group 1 & $43.20 \pm 1.893$ & \multirow{2}{*}{$-2.5^{*}$} & \multirow{2}{*}{86.0} \\
\hline & Group 2 & $56.30 \pm 3.228$ & & \\
\hline \multicolumn{5}{|c|}{ Leonhard-Schmischek's method for determining character accentuation } \\
\hline \multirow{2}{*}{ Demonstrativeness } & Group 1 & $12.600 \pm .7960$ & \multirow{2}{*}{$-7.1 * * *$} & \multirow{2}{*}{61.0} \\
\hline & Group 2 & $20.700 \pm .8114$ & & \\
\hline \multirow{2}{*}{ Dysthymia } & Group 1 & $16.350 \pm .9605$ & \multirow{2}{*}{$3.3^{* *}$} & \multirow{2}{*}{138.0} \\
\hline & Group 2 & $11.850 \pm .9355$ & & \\
\hline \multirow{2}{*}{ Anxiety } & Group 1 & $14.700 \pm 1.3399$ & \multirow{2}{*}{$-2.3^{*}$} & \multirow{2}{*}{78.0} \\
\hline & Group 2 & $18.750 \pm 1.1283$ & & \\
\hline \multirow{2}{*}{ Cyclothymic } & Group 1 & $13.800 \pm 1.0301$ & \multirow{2}{*}{$2.4^{*}$} & \multirow{2}{*}{135.0} \\
\hline & Group 2 & $10.200 \pm 1.0751$ & & \\
\hline \multirow{2}{*}{ Exaltation } & Group 1 & $12.400 \pm 1.2191$ & \multirow{2}{*}{$-2.5^{*}$} & \multirow{2}{*}{75.0} \\
\hline & Group 2 & $16.600 \pm 1.1526$ & & \\
\hline \multirow{2}{*}{ Emotionality } & Group 1 & $9.150 \pm 1.3500$ & \multirow{2}{*}{$-3.7 * *$} & \multirow{2}{*}{60.0} \\
\hline & Group 2 & $15.300 \pm .9208$ & & \\
\hline
\end{tabular}

Note: Group $1-$ (males, $\mathrm{n}=49$ ); Group $2-$ (females, $\mathrm{n}=52) ; *-\mathrm{p} \leq .05 ; * *-\mathrm{r} \leq .01 ; * * *-\mathrm{r} \leq .001 ; \mathrm{M}-$ mean; $\mathrm{SD}$ - Standard deviation.

An important question is how the personal characteristics of Group 1 and Group 2 respondents affect their psychological well-being when they are isolated from others (Table 2). 


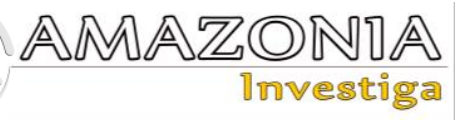

Table 2.

Psychological well-being and personal characteristics of Group 1 and Group 2 respondents according to Student's t-Test criterion.

\begin{tabular}{|c|c|c|c|c|}
\hline Indicator & Gender & $\mathbf{M} \pm \mathbf{S D}$ & $\begin{array}{l}\text { Student's t- } \\
\text { Test }\end{array}$ & $\Delta, \%$ \\
\hline \multicolumn{5}{|l|}{ MMPI } \\
\hline Hypochondria & $\begin{array}{l}\text { Group } 1 \\
\text { Group } 2\end{array}$ & $\begin{array}{l}52.35 \pm 2.297 \\
65.05 \pm 2.318\end{array}$ & $-2.2 *$ & 81.0 \\
\hline Depression & $\begin{array}{l}\text { Group } 1 \\
\text { Group } 2\end{array}$ & $\begin{array}{l}51.75 \pm 2.242 \\
58.70 \pm 2.315\end{array}$ & $-2.2^{*}$ & 89.0 \\
\hline Hysteria & $\begin{array}{l}\text { Group } 1 \\
\text { Group } 2\end{array}$ & $\begin{array}{l}50.60 \pm 3.033 \\
61.60 \pm 3.487\end{array}$ & $-2.4^{*}$ & 83.0 \\
\hline Hypomania & $\begin{array}{l}\text { Group } 1 \\
\text { Group } 2\end{array}$ & $\begin{array}{l}57.80 \pm 3.043 \\
48.25 \pm 2.310\end{array}$ & $2.5^{*}$ & 119.0 \\
\hline \multicolumn{5}{|c|}{ The Warwick-Edinburgh Mental Well-being Scale } \\
\hline $\begin{array}{l}\text { Psychological well- } \\
\text { being }\end{array}$ & $\begin{array}{l}\text { Group } 1 \\
\text { Group } 2\end{array}$ & $\begin{array}{l}46.03 \pm 10.329 \\
50.50 \pm 9.437\end{array}$ & $2.3^{*}$ & 129.0 \\
\hline
\end{tabular}

Note: Group 1 - (males, $\mathrm{n}=49)$; Group 2 - (females, $\mathrm{n}=52){ }^{*}$ - $\mathrm{p} \leq .05 ; \mathrm{M}-$ mean; SD - standard deviation.

The study discovered the following patterns in students' modal choice of geometric shapes and colors based on gender (Table 3).

Table 3.

Modal distribution and relationship of parameters according to the method of S. Dellinger and parameters according to the color test M. Luscher in Group 1 and Group 2.

\begin{tabular}{llll}
\hline Modal & \multicolumn{2}{l}{ Color selection rank in the test } & \multirow{2}{*}{ F test } \\
\cline { 2 - 3 } distribution & Group 1 & Group 2 & .136 \\
Triangle & 1 & 1 & .147 \\
Box & 3 & 2 & .154 \\
Circle & 3 & 1 & .122 \\
Rectangle & 4 & 4 & .134 \\
Squiggle & 5 & 5 & .210 \\
Blue & 1 & 1 & .009 \\
Green & 6 & 7 & .038 \\
Red & 5 & 8 & .008 \\
Yellow & 8 & 3 & .156 \\
Purple & 4 & 2 & .007 \\
Brown & 2 & 4 & .000 \\
Black & 7 & 7 & .009 \\
Gray & 3 & 5 & \\
\hline
\end{tabular}

A statistically significant F-test value indicates that the metric variable hierarchy of geometric shapes and color choice distribution is observed to be dependent on the nominal variable (boys / girls).

\section{Discussion}

The disease outbreak has a detrimental effect on the younger generation's psycho-emotional side of life, as well as on the social, isolating people in all aspects of this concept. While most studies have investigated the effects of the global epidemic on demography mental health are fragmentary and contradictory, research on this topic is extremely necessary and relevant. A great deal of research has discovered proof of the pandemic's impact on women, men, and other gender groups, including emotional stress and various types of mental disorders (Rana et al, 2021)

The presence of depressive-anxiety as well as hypochondriac episodes in respondents was the study's hypothesis, which was confirmed by the findings. 
The study of the state of anxiety revealed that the dynamics of change in this state are more prevalent in Group 2 than in Group 1 as the coronavirus pandemic progressed. The results of mathematical and statistical processing demonstrate the outlined trend convincingly. Differences in personal anxiety levels between boys (Group 1) and girls (Group 2) differ in the average value $(\mathrm{M})$ : girls $-56.30 \pm 3.228$; boys $43.20 \pm 1.893$ points $(\mathrm{p}=.05)$. The prevalence of anxiety in girls is due to their emotionality, greater susceptibility to difficulties adapting to social isolation, and concern for their health and the safety of their family and friends. According to the comparative analysis, such indicators as dysthymia $-16.350 \pm .96(\mathrm{p}=.05)$, exaltation $16.200 \pm 1.18$ points, cyclothymia $-13.800 \pm$ $1.03(\mathrm{p}=.05)$ predominate among boys. The guys, according to our observations, are characterized by frequent periodic mood swings. They are distinguished by low contact and silence, which alleviates the discomfort caused by the restriction of social contacts during a pandemic. In female students, the following dominant accentuations were established: demonstrativeness $-2.700 \pm .81$ points $(\mathrm{p}<.001)$, anxiety $-18.750 \pm 1.12$ points $(\mathrm{p}<.05)$, exaltation $-16.600 \pm 1.15$ points $(\mathrm{p}<.05)$ and emotionality $-15.300 \pm .92$ points $(\mathrm{p}<.01)$. Girls, according to our observations, are characterized by demonstrative behavior and a desire for constant attention. According to the findings, the severity of anxiety is caused by a proclivity to panic in response to various events. Excessive health care is related to increased personal anxiety among girls, which reduces activity, impoverishes interests, and further distracts from public life. Our findings support the findings of other researchers regarding changes in the psychological state of student youth during a pandemic. Thus, Hawke and colleagues (2020) discovered that mental health of young people deteriorated, particularly in the form of melancholy and tension. Some other research proves that there is a high level of anxiety in young people, though lower levels have been reported in men and young people who exercise regularly (Chen et al., 2020).

Girls are characterized by increased sensitivity, a fear of their health, timidity, and dissatisfaction with themselves and their abilities, according to the dominant personality type. Girls, in our opinion, are anxious and distrustful individuals who struggle with empathy and social isolation, lowering their level of psychological well-being. Because of abrupt changes in living conditions, experiences related to learning and the family situation, and the possibility of infection, the lockdown situation causes episodes of depression in girls (Hudimova, 2021; Hudimova et al., 2021).

For boys-students, the following characteristics stand out: failures in educational activities due to the transition to distance learning do not cause anxiety or depression. The main characteristic is a positive attitude regardless of the circumstances. They are active, active, energetic, and capable of diverting attention away from other aspects of isolated life. The desire for something new becomes a kind of coping strategy for boys, maintaining an average level of psychological well-being. Our findings support the findings of other researchers that, regardless of the circumstances, boys are less vulnerable to negative psychological consequences (Filippova \& Saliu, 2021; Sanchez-Teurel et al., 2021; Baghurst et al., 2014; Gefen \& Fish, 2012).

There is a link between "Rectangle" and purple in boys, which can be seen in a more or less conscious state of confusion, ambiguity in problems, and uncertainty about themselves at the moment. Characterized by low self-esteem, a desire to succeed in their activities, inconsistency in actions, increased criticism of others and restraint in expressing their emotions, and apprehension about becoming deeply involved in any personal or educational relationship. As a result, the situation of forced isolation is viewed as a chance to unwind and prepare for future socially significant relationships.

The relationship between the "Triangle" and the yellow color in both groups is explained by energy, ambition, a tendency to leadership, a focus on success in the activity - the opportunity to express themselves in learning.

Modal choice "Box" in the group of girls demonstrates: organization and planning of educational activities in accordance with current self-isolation rules, as well as the ability to work out all the specific details of current ideas and opportunities to improve their psycho-emotional state. Girls place a high value on harmony in interpersonal relationships because they have strong empathy and a proclivity to avoid conflict. The first modal choice of "Circle" for girls demonstrates that with the assistance of online learning, they can continue to actively participate in the social activities of higher education institutions and enjoy it greatly. Despite the fact that there is a decrease in mood and physical fatigue as a result of the almost non-existent competent daily routine. 


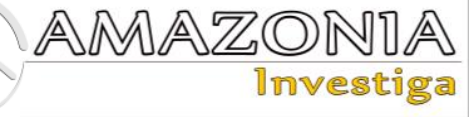

"Working group (green, red)" is disintegrated and chosen by girls in the 7th and 8th positions, who are characterized by apathy and antipathy toward these colors. Girls do not associate these colors with their current situation, mood, or motivation. Respondents have a negative mental state that is similar to stress and emotional dissatisfaction, which is compensated for by fantasizing and striving for bright events in life that will occur after quarantine. This could explain why this group of students is so active in various amateur groups, even with the help of video conferencing applications. Female students have higher levels of anxiety and disbelief in their abilities, and they avoid learning situations where they can demonstrate their incompetence.

Gray is clearly the third most popular color in both boys and girls. Gray is a neutral color. There are violations of interpersonal relationships and a decrease in academic performance when people "escape" into the inner world or virtual space to distract themselves from negative experiences.

Consequently, using project methods, the respondents' personal characteristics are embossed, which is reflected in their modal choices.

The situation created by the global epidemic is astounding in terms of the psychological consequences of forced social isolation (Brooks, 2020; Golberstein et al, 2020). Thus, it can be stated that mental disorders are observed as a consequence of various life changes of student youth as an outcome of the pandemic, with an advantage among the female population, that has detrimental ramifications for psychological wellbeing and overall health.

\section{Conclusions}

1. Group 1 respondents (girls, $\mathrm{n}=52$ ) have a more pronounced anxiety development dynamic $(\mathrm{M}=56.30 \pm 3.228)$. The girls perceive self-isolation as a direct threat, which not only disrupts the normal rhythm of life, but can also lead to illness, poor academic performance, future employment opportunities, and basic social relations.

2. Despite the decline in academic performance, there were fewer manifestations of stress and low mood among Group 2 respondents (boys, $n=49$ ). The boys chose to be distracted by the virtual world or other activities as a coping strategy, which kept their psychological well-being at an acceptable level $(\mathrm{t}=2.3 ; \mathrm{p}=.05)$. However, the strategy of overcoming emotions as an avoidance of thoughts about the current situation has protracted negative outcomes for mental health, specifically the development of depression symptoms $(\mathrm{M}=51.75 \pm 2.242)$.

3. To cope with the stress of a pandemic, it has been discovered that girls frequently use video communication to support communication with friends / selfgovernment of an educational institution. However, the relationship between social networks and the Internet in general for psychological well-being is highly debated, as evidenced by a number of studies.

4. The study adds to the growing domain of research about the psychological content parameters of an impact of coronavirus pandemic on student youth's psychological well-being. The study's findings should be implemented in the organization of higher education institutions' educational processes; important parameters should be considered when planning educational and upbringing activities for student youth.

\section{Bibliographic references}

Baghurst, T., \& Kelley, B. C. (2014). An Examination of Stress in College Students Over the Course of a Semester. Health Promotion Practice, 15(3), 438-447. https://doi.org/10.1177/1524839913510316

Besser, A., Flett, G. L., \& Zeigler-Hill, V. (2020). Adaptability to a sudden transition to online learning during the COVID-19 pandemic: Understanding the challenges for students. Scholarship of Teaching and Learning in Psychology. https://doi.org/10.1037/st10000198

Blynova, O., Kisil, Z. et al. (2020). Psychological manifestations of professional marginality of future social welfare professionals. Revista Inclusiones, $\quad 7(\mathrm{SI}), \quad$ 218-233. http://www.revistainclusiones.org/index.php /inclu/article/view/1229

Broche-Pérez, Y., Fernández-Fleites, Z. Et al. (2020). Gender and Fear of COVID-19 in a Cuban Population Sample. International Journal of Mental Health and Addiction. https://doi.org/10.1007/s11469-020-00343-8

Brooks, S. K., Webster, R. K. et al. (2020). The psychological impact of quarantine and how to reduce it: rapid review of the evidence. The lancet, 395(10227), 912-920. https://doi.org/10.1016/S01406736(20)30460-8

Chang, W. H. (2020). Understanding the COVID-19 pandemic from a gender perspective. Taiwanese Journal of Obstetrics 
\& Gynecology, 59(6), 801-807. https://doi.org/10.1016/j.tjog.2020.09.004

Charles, N. E., Strong, S. J. et al. (2021). Increased mood disorder symptoms, perceived stress, and alcohol use among college students during the COVID-19 pandemic. Psychiatry research, 296, 113706. https://doi.org/10.1016/j.psychres.2021.1137 06

Chen, F., Zheng, D. et al. (2020). Depression and anxiety among adolescents during COVID19: a cross-sectional study. BRAIN, Behavior, and Immunity, 88, 36-38. https://doi.org/10.1016/j.bbi.2020.05.061

Cielo, F., Ulberg, R., \& Di Giacomo, D. (2021). Psychological Impact of the COVID-19 Outbreak on Mental Health Outcomes among Youth: A Rapid Narrative Review. International Journal of Environmental Research and Public Health, 18(11), 6067. https://doi.org/10.3390/ijerph18116067

Dalton, L., Rapa, E., \& Stein, A. (2020). Protecting the psychological health of children through effective communication about COVID-19. The Lancet Child \& Adolescent Health, 4(5), 346-347. https://doi.org/10.1016/S23524642(20)30097-3

Daly, M., Sutin, A., R., \& Robinson, E. (2020). Longitudinal Changes in Mental Health and the COVID-19 Pandemic: Evidence from the UK Household Longitudinal Study. Psychological Medicine; First View, 1-10. https://doi.org/10.1017/S0033291720004432

Dang, H., \& Nguyen, V., C (2020). Gender Inequality during the COVID-19 Pandemic: Income, Expenditure, Savings, and Job Loss. Institute of Labor Economics (IZA). https://www.iza.org/publications/dp/13824/g ender-inequality-during-the-covid-19pandemic-income-expenditure-savings-andjob-loss

Dellinger, S. (1989). Psycho-geometrics: How to use geometric psychology to influence people. Prentice Hall Direct. https://www.utm.edu/staff/sbyrd/Psychogeo metrics.pdf

Fegert, J. M., Vitiello, B., Plener, P. L., \& Clemens, V. (2020). Challenges and burden of the Coronavirus 2019 (COVID-19) pandemic for child and adolescent mental health: a narrative review to highlight clinical and research needs in the acute phase and the long return to normality. Child and adolescent psychiatry and mental health, 14, 1-11. https://doi.org/10.1186/s13034-02000329-3

Filippova, E., \& Saliu, F. (2021). Gender and Stress of COVID-19 in College Students of the Czech Republic (Master Thesis), University of New York in Prague. Retrieved from

https://elearning.unyp.cz/pluginfile.php/581 41/mod_data/content/8448/Saliu\%2C\%20Fi ona\%20\%28514707\%29\%20-

$\% 20$ Master\%20Thesis.pdf

Fiorillo, A., \& Frangou, S. (2020). European Psychiatry 2020: Moving forward. European Psychiatry, 63(1), E1. https://doi.org/10.1192/j.eurpsy.2019.3

Gefen, D. R., \& Fish, M. C. (2012). Gender Differences in Stress and Coping in FirstYear College Students. Journal of College Orientation, Transition, and Retention, 19(2). https://doi.org/10.24926/jcotr.v19i2.2797

Giordani, R., Formighieri, C., Ruiz Giolo, S., Muhl, C. and Zanoni da Silva, M. (2021). Psychometric Evaluation of the Portuguese Version of the FCV-19 Scale and Assessment of Fear of COVID-19 in a Southern Brazilian Population. Journal of Human Behavior in the Social Environment; 31(1-4): 145-153. https://doi.org/10.1080/10911359.2020.1854 142

Golberstein, E., Wen, H., and Miller, B. F. (2020). Coronavirus Disease 2019 (COVID19) and Mental Health for Children and Adolescents. JAMA Pediatr., 174, 819-820. https://doi.org/10.1001/jamapediatrics.2020. 1456

Hawke, L. D., Barbic, S. P. et al. (2020). Impacts of COVID-19 on Youth Mental Health, Substance Use, and Well-being: A Rapid Survey of Clinical and Community Samples. The Canadian Journal of Psychiatry, 65(10), 701-709. https://doi.org/10.1177/0706743720940562

Halian, A., Halian, I. et al. (2020). Emotional Intelligence in the Structure of Adaptation Process of Future Healthcare Professionals. Revista Inclusiones, 7(3), 447-460. http://www.revistainclusiones.org/index.php /inclu/article/view/1347

Hossain, M., M., Tasnim, S. et al. (2020). Epidemiology of Mental Health Problems in COVID19: A Review. F1000Res, 9, 636. https://doi.org/10.12688/f1000research.2445 7.1

Hudimova, A. Kh. (2021). Behavioral Patterns of Social Media Users as a Condition of Their Psychological Well-being. (PhD thesis), Odesa National I. I. Mechnikov University Online Repository. Retrieved from http://onu.edu.ua/pub/bank/userfiles/files/sci ence/razovi_spec_vcheni_rady/df41051014/ diss_GudimovaAH.pdf

Hudimova, A., Popovych, I. et al. (2021). The impact of social media on young web users' 


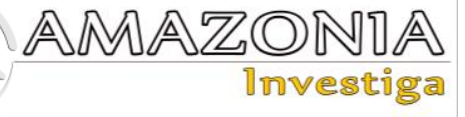

psychological well-being during the COVID19 pandemic progression. Revista Amazonia Investiga, $\quad 10(39)$, 50-61. https://doi.org/10.34069/AI/2021.39.03.5

Huckins, J. F., DaSilva, A. W. et al. (2020). Mental health and behavior of college students during the early phases of the COVID-19 pandemic: Longitudinal smartphone and ecological momentary assessment study. Journal of Medical Internet Research, 22(6), e20185. https://doi.org/10.2196/20185

Idowu, A., Olawuyi, D. A., \& Nwadioke, C. O. (2020). Impacts of CoVID-19 pandemic on the psychological well being of students in a Nigerian university. Journal of Medical and Surgical Research, 7(3), 798-806. https://pesquisa.bvsalud.org/globalliterature-on-novel-coronavirus-2019. ncov/resource/en/covidwho-1049333

Kang, L., Ma, S. et al. (2020). Impact on mental health and perceptions of psychological care among medical and nursing staff in Wuhan during the 2019 novel coronavirus disease outbreak: A cross-sectional study. BRAIN, behavior, and immunity, 87, 11-17. https://doi.org/10.1016/j.bbi.2020.03.028

Khan, A. H., Sultana, M. S. et al. (2020). The impact of COVID-19 pandemic on mental health and wellbeing among homequarantined Bangladeshi students: a crosssectional pilot study. Journal of affective disorders, 277, 121-128. https://doi.org/10.31234/osf.io/97s5r

Khmiliar, O., Popovych, I. et al. (2020). Spatial Regulation of Personality Behavior in the Conditions of Progression of the COVID-19 Pandemic. Revista Inclusiones, 7(Especial), 289-306.

http://www.revistainclusiones.org/index.php /inclu/article/view/1760

Leonhard, K. (1981). Accentuated personalities. Kyiv: Higher School. https://lib.unidubna.ru/search/files/psy_leongard/1.pdf

Levita, L., Miller, J. G. et al. (2020). Report1: Impact of Covid-19 on young people aged 13-24 in the UK-preliminary findings. https://doi.org/10.31234/osf.io/uq4rn

Luscher, M., \& Scott, I. (1971). The Luscher Color Text: The Remarkable Test That Reveals Your Personality Through Color. Trans: Ian Scott. New York: WSP/Pocket Books.

https://archive.org/details/luschercolortest00 drma/page/n193/mode/2up

Mekonen, E. G., Workneh, B. S. et al. (2021). The psychological impact of COVID-19 pandemic on graduating class students at the University of Gondar, northwest Ethiopia.

Psychology research and behavior management, $14,109$. https://doi.org/10.2147/PRBM.S300262

Merlo, E. M., Sicari, F. et al. (2021). Uncertainty, alexithymia, suppression and vulnerability during the COVID-19 pandemic in Italy. Health Psychology Report, 9(2), 169-179. https://pesquisa.bvsalud.org/globalliterature-on-novel-coronavirus-2019ncov/resource/en/covidwho-1200286

Nosov, P., Palamarchuk, I. et al. (2020a). Development of means for experimental identification of navigator attention in ergatic systems of maritime transport. Bulletin of the University of Karaganda - Physics, 1(97), 58-69. https://doi.org/10.31489/2020Ph1/58-69

Nosov, P. S., Zinchenko, S. M. et al. (2020b). Diagnostic system of perception of navigation danger when implementation complicated maneuvers. Radio Electronics, Computer Science, Control, 1, 146-161. https://doi.org/10.15588/1607-3274-2020-115

Ozer, M. (2020). Educational policy actions by the Ministry of National Education in the times of COVID-19 pandemic in Turkey. Kastamonu Educational Journal, 28(3), 1124-1129.

http://doi.org/10.24106/kefdergi.722280

Padrón, I., Fraga, I., Vieitez, L., Montes, C., \& Romero, E. (2021). A study on the psychological wound of COVID-19 in university students. Frontiers in psychology, 12 https://doi.org/10.3389/fpsyg.2021.589927

Parola, A., Rossi, A., Tessitore, F. et al. (2020). Mental health through the COVID-19 quarantine: a growth curve analysis on Italian young adults. Frontiers in psychology, 11. https://doi.org/10.3389/fpsyg.2020.567484

Pieh, C., Budimir, S., \& Probst, T. (2020). The effect of age, gender, income, work, and physical activity on mental health during coronavirus disease (COVID-19) lockdown in Austria. Journal of psychosomatic research, 136, 110186. https://doi.org/10.1016/j.jpsychores.2020.11 0186

Pigaiani, Y., Zoccante, L. et al. (2020). Adolescent lifestyle behaviors, coping strategies and subjective wellbeing during the COVID-19 pandemic: an online student survey. In Healthcare, 8(4), p. 472. Multidisciplinary Digital Publishing Institute. https://doi.org/10.3390/healthcare8040472

Popovych, I., Arbeláez-Campillo, D. F. et al. (2021a). Time perspective in the professional 
activity of specialists of economic sphere. Cuestiones Políticas, 39(69), 424-445. https://doi.org/10.46398/cuestpol.3969.27

Pinkovetskaia, I., Arbeláez-Campillo, D. F. et al. (2021). Entrepreneurship for the elderly in Russia: situation and prospects. Amazonia Investiga, $\quad$ 10(39), 94-101. https://doi.org/10.34069/AI/2021.39.03.9

Popovych, I., Shevchenko, A. et al. (2021b). Research of the relationship between social desirability and value orientations of adolescents. Revista Notas Históricas y Geográficas, 26(1), 241-268. https://www.revistanotashistoricasygeografi cas.cl/index.php/nhyg/article/view/339

Popovych, I., Zhigarenko, I. et al. (2020a). Research of Achievement Motivation's Impaction the Career Orientations of Future Managers of Organization. RI, 7(SI), 247-263.

http://www.revistainclusiones.org/index.php /inclu/article/view/1231

Proto, E., \& Quintana-Domeque, C. (2021). COVID-19 and Mental Health Deterioration by Ethnicity and Gender in the UK. PLOS ONE, 16(1), e0244419. https://doi.org/10.1371/journal.pone.024441 9

Rana, A., I., Bhatti, S., S. et al. (2021). COVID19 risk perception and coping mechanisms: Does gender make a difference? International Journal of Disaster Risk Reduction, 55. https://doi.org/10.1016/j.ijdrr.2021.102096

Ranieri, J., Guerra, F., \& Di Giacomo, D. (2021). Predictive risk factors for post-traumatic stress symptoms among nurses during the Italian acute COVID-19 outbreak. Health Psychology Report, 9(2), 180-185. https://doi.org/10.5114/hpr.2020.101249

Ravens-Sieberer, U., Kaman, A. et al. (2021). Impact of the COVID-19 pandemic on quality of life and mental health in children and adolescents in Germany. European child \& adolescent psychiatry, 1-11. https://doi.org/10.1007/s00787-021-01726-5

Rossi, R., Socci, V. et al. (2020). COVID-19 pandemic and lockdown measures impact on mental health among the general population in Italy. Frontiers in psychiatry, 11, 790. https://doi.org/10.3389/fpsyt.2020.00790

Sánchez-Teruel, D., Robles-Bello, M. A., \& Valencia-Naranjo, N. (2021). Do psychological strengths protect college students confined by COVID-19 to emotional distress? The role 84 of gender. Personality and Individual Differences, 171. https://doi.org/10.1016/j.paid.2020.110507
Shevchenko, R., Cherniavskyi, V. et al. (2020a). Research of psychophysiological features of response to stress situations by future sailors. Revista Inclusiones, 7(SI), 566-579. http://www.revistainclusiones.org/index.php /inclu/article/view/1780

Shevchenko, R., Popovych, I. et al. (2020b). Comparative analysis of emotional personality traits of the students of maritime science majors caused by long-term staying at sea. Revista Inclusiones, 7(Especial), 538-554.

http://www.revistainclusiones.org/index.php /inclu/article/view/1309

Singh, S., Roy, D. et al. (2020). Impact of COVID-19 and lockdown on mental health of children and adolescents: a narrative review with recommendations [Internet]. Psychiatry Res. Elsevier Ireland Ltd. https://doi.org/10.1016/j.psychres.2020.1134 29

Tennant, R., Hiller, L. et al. (2007). The Warwick-Edinburgh Mental Well-being Scale (WEMWBS): Development and UK validation. Health and Quality of Life Outcomes, 5(63). https://doi.org/10.1186/1477-7525-5-63

Vagg, P.R., Spielberger, C.D., \& O'Hearn, Jr, T.P. (1980). Is the state-trait anxiety inventory multidimensional?. Personality and Individual Differences, 1(3), 207-214. https://doi.org/10.1016/01918869(80)90052-5

Villani, L., Pastorino, R. et al. (2021). Impact of the COVID-19 pandemic on psychological well-being of students in an Italian university: a web-based cross-sectional survey. Globalization and health, 17(1), 1-14. https://doi.org/10.1186/s12992-021-00680-w

Vindegaard, N., \& Benros, M., E. (2020). COVID-19 Pandemic and Mental Health Consequences: Systematic Review of the Current Evidence. BRAIN, Behavior, and Immunity, 89, 531-542. https://doi.org/10.1016/j.bbi.2020.05.048

Whitman, M. R., Tylicki, J. L. et al. (2020). Psychometric properties of the Minnesota Multiphasic Personality Inventory-3 (MMPI-3) in a clinical neuropsychology setting. Psychological Assessment. https://doi.org/10.1037/pas0000969

Wilczyńska, D., Li, J. et al. (2021). Fear of COVID-19 changes the motivation for physical activity participation: PolishChinese comparisons. Health Psychology Report, 9(2), 138-148. https://czasopisma.bg.ug.edu.pl/index.php/H $\mathrm{PR} /$ article/view/5754 


\section{AMAZOND周 \\ 1nvestiga}

Xiong, J., Lipsitz, O. et al. (2020). Impact of COVID-19 Pandemic on Mental Health in the General Population: A Systematic Review. Journal of Affective Disorders, 277, 55-64. https://doi.org/10.1016/j.jad.2020.08.001

Yunus, W. M., Badri, S. K. et al. (2020). The Unprecedented Movement Control Order (Lockdown) and Factors Associated With the Negative Emotional Symptoms, Happiness, and Work-Life Balance of Malaysian University Students During the Coronavirus Disease (COVID-19) Pandemic. Frontiers in psychiatry, 11. https://doi.org/10.3389/fpsyt.2020.566221

Zaitsev, Yu. A., \& Khvan, A. A, (2011). Standardization of methods for diagnosing of the anxiety by Spielberger-Hanin and
J. Taylor. Psykholohichna diahnostyka, 3, 19-34.

Zinchenko, S. M., Ben, A. P. et al. (2020). Improving the accuracy and reliability of automatic vessel moution control system. Radio Electronics, Computer Science, Control, 2, 183-195. https://doi.org/10.15588/1607-3274-2020-219

Zhou, S. J., Zhang, L. G. et al. (2020). Prevalence and socio-demographic correlates of psychological health problems in Chinese adolescents during the outbreak of COVID19. European child and adolescent psychiatry, 29(6), 749-758. https://doi.org/10.1007/s00787-020-01541-4 